\title{
TEKNIK VOLTAMETRI PELUCUTAN ANODIK GELOMBANG PERSEGI UNTUK PENENTUAN KADAR LOGAM CU DALAM KANGKUNG AIR
}

\author{
Irdhawati Irdhawati ${ }^{*}$, Liana Sari, Ida Ayu Raka Astiti Asih \\ ${ }^{1}$ Jurusan Kimia Fakultas Matematika dan Ilmu Pengetahuan Alam \\ Universitas Udayana \\ "email:irdhawati@unud.ac.id
}

Received 6 July 2016

Accepted 30 November 2016

\begin{abstract}
Abstrak
Analisis logam berat $\mathrm{Cu}$ (II) dilakukan dengan metode voltametri pelucutan anodik gelombang persegi. Penelitian ini bertujuan untuk mengetahui validitas metode voltametri pelucutan anodik yang digunakan dalam pengukuran kadar logam $\mathrm{Cu}$ (II) dalam sampel kangkung air di muara sungai Badung. Elektroda glassy carbon digunakan sebagai elektroda kerja, $\mathrm{Ag} / \mathrm{AgCl}$ sebagai elektroda pembanding, dan kawat platina sebagai elektroda pembantu. Parameter yang dioptimasi meliputi waktu deposisi dan laju pindai dalam larutan standar $\mathrm{Cu}$ (II) $500 \mathrm{ppb}$. Validasi metode ditentukan dengan menentukan rentang konsentrasi linier, limit deteksi, keberulangan pengukuran, dan persen perolehan kembali. Teknik voltametri pelucutan anodik kemudian digunakan untuk mengukur kadar logam $\mathrm{Cu}$ (II) pada sampel kangkung air. Hasil optimasi pengukuran kadar logam $\mathrm{Cu}$ (II) yaitu waktu deposisi optimum 60 detik dan laju pindai optimum $10 \mathrm{mV} /$ detik. Pengukuran validitas larutan standar logam $\mathrm{Cu}$ (II), rentang konsentrasi linier larutan $50-500 \mathrm{ppb}$ dan memiliki koefisien korelasi 0,9983. Limit deteksi $35 \mathrm{ppb}$, keberulangan pengukuran memiliki rasio Horwitz kurang dari 2, dan persen perolehan kembali 99,35\% $\pm 0,45$. Hasil pengukuran sampel tanaman kangkung memiliki kandungan logam $\mathrm{Cu}$ (II) sebesar 4,0 ppm (tidak melebihi kadar maksimum yang diperkenankan).
\end{abstract}

Kata kunci: Logam berat Cu (II), voltametri pelucutan anodik gelombang persegi dan kangkung air

\begin{abstract}
Heavy metal analysis of $\mathrm{Cu}$ (II) was measured by square wave anodic stripping voltammetry method.The aim of this research is to know the validity of square wave anodic stripping voltammetry method for determination of $\mathrm{Cu}$ (II) in water spinach from the estuary of Badung river.Glassy carbon, $\mathrm{Ag} / \mathrm{AgCl}$, and $\mathrm{Pt}$ wire electrodes were used as working electrode, reference electrode and counter electrode, respectively. Optimized parameter involved the deposition time and scan rate in standard solution $\mathrm{Cu}$ (II) $500 \mathrm{ppb}$. Furthermore, the validation method was examined by determination of linear concentration range, limit of detection, repetition of measurement, and percent of recovery. Moreover, the result of validation was used for observing of heavy metal $\mathrm{Cu}$ (II) content in water spinach. The result of optimum deposition time is $60 \mathrm{~s}$. Meanwhile, the scan rate optimum is $10 \mathrm{mV} / \mathrm{s}$. Measurement for standard solution $50-500 \mathrm{ppb}$ on linear concentration range, with correlation coefficient 0,9983 . Limit of detection is $35 \mathrm{ppb}$, repetition of measurement for metal has Horwitz ratio less than 2, and percent recovery of
\end{abstract}


$\mathrm{Cu}$ (II) measurement is $99,35 \% \pm 0,45$. The measurement of $\mathrm{Cu}$ (II) content in the water spinach sample contain $\mathrm{Cu}(\mathrm{II})$ 4,0 ppm (accepted value).

Keywords: Heavy metal Cu (II), square wave anodic stripping voltammetry and water spinach.

\section{Pendahuluan}

Seiring dengan meningkatnya taraf hidup masyarakat, tingkat kebutuhan juga akan semakin meningkat dan dalam memenuhi kebutuhannya manusia seringkali menghasilkan dampak yang negatif terhadap lingkungan. Hasil dari aktivitas manusia ini menyebabkan terjadinya pencemaran ke lingkungan. Pencemaran yang terjadi mengakibatkan turunnya kualitas tanah dan air. Salah satu tanaman yang pada umumnya mudah tumbuh di tanah atau tepian air adalah kangkung.Kangkung dapat tumbuh di berbagai daerah di Indonesia dan merupakan tanaman yang tidak selektif terhadap unsur hara tertentu, sehingga dapat menyerap semua unsur di dalam tanah atau air (Rachman, 2009).

Penggunaan pupuk, pestisida dan pembuangan limbah ke sungai dapat menyebabkan tanaman kangkung terkontaminasi dengan logam berat. Logam $\mathrm{Cu}$ banyak digunakan sebagai pestisida pembasmi jamur dan cacing pada tanaman sayur dan buah. Garam $\mathrm{Cu}$ juga digunakan sebagai bahan dari larutan Bordeaux yang mengandung 1-3 \% CuSO4 untuk membasmi jamur, siput dan cacing (Darmono, 1995).

Beberapa metode telah digunakan untuk analisis kandungan logam dalam tanaman, diantaranya adalah elektroanalisis. Metode elektroanalisis, dalam hal ini voltametri merupakan salah satu metode analisis yang paling sensitif dengan limit deteksi yang sangat rendah sampai pada konsentrasi ppb dan juga dapat dilakukan dengan peralatan yang sederhana dengan biaya yang relatif murah bila dibandingkan dengan instrumen lainnya (Widayah, 2010). Voltametri adalah metode elektrokimia melalui pengamatan arus dengan pemberian potensial tertentu. Analisis logam berat menggunakan metode voltametri pelucutan anodik gelombang persegi (Square Wave Anodic Stripping Voltammetry) menggunakan elektroda glassy carbon sebagai elektroda kerja. Metode ini memiliki sensitivitas yang tinggi dan mudah untuk menentukan ionion didalam larutan tanpa harus dilakukan pemisahan unsur-unsur utamanya (Wang, 2001).

Validasi metode analisis merupakan suatu tindakan pembuktian terhadap parameter tertentu yang dilakukan berdasarkan pengujian secara obyektif di laboratorium, untuk membuktikan parameter itu memenuhi persyaratan yang telah ditentukan sesuai dengan tujuan penggunaannya. Dalam validasi metode analisis ada beberapa parameter analisis yang harus dipertimbangkan yaitu: rentang konsentrasi linear, kecermatan atau persen perolehan kembali (recovery), kesaksamaan atau keberulangan (repeatability), selektivitas batas deteksi dan batas kuantitas, ketangguhan metode (rugged-ness) (Harmita, 2004).

Pada penelitian ini dilakukan validitas metode voltametri pelucutan anodik yang digunakan dalam pengukuran kadar logam $\mathrm{Cu}$ (II) dalam sampel kangkung air yang diambil di muara sungai Badung. Parameter yang dioptimasi yaitu waktu deposisi dan laju pindai, sedangkan parameter validasi yang diuji meliputi rentang linier, limit deteksi, keberulangan (ketelitian), dan ketepatan (perolehan kembali). Selanjutnya pada kondisi optimum, pengukuran logam $\mathrm{Cu}$ (II) dalam sampel kangkung air dilakukan menggunakan elektroda glassy carbon. 
Metode Penelitian

Alat dan Bahan

Peralatan yang digunakan dalam penelitian ini adalah: hot plate, perangkat peralatan voltameter yang terdiri dari Instrumen Potensiostat Ingsens 1030, elektroda glassy carbon (BAS) sebagai elektroda kerja, elektroda $\mathrm{Ag} / \mathrm{AgCl}(\mathrm{KCl}$ $0,1 \mathrm{M})$ hand made sebagai elektroda pembanding dan Pt koil sebagai elektroda pembantu, neraca analitik (Shimadzu), pengaduk magnetik, adaptor, pipet mikro (Socorex), polishing sheet, serta peralatan laboratorium pada umumnya seperti gelas beaker, pipet dan labu ukur. Bahan-bahan yang digunakan pada penelitian ini adalah: aqua regia, alumina slurry 0,05 $\mu \mathrm{m}$, larutan $\mathrm{HNO}_{3}, \mathrm{KCl}, \mathrm{H}_{2} \mathrm{SO}_{4}$, $\mathrm{CuSO}_{4} .5 \mathrm{H}_{2} \mathrm{O}, \quad \mathrm{K}_{4} \mathrm{Fe}(\mathrm{CN})_{6} .3 \mathrm{H}_{2} \mathrm{O}$, $\mathrm{K}_{3} \mathrm{Fe}(\mathrm{CN})_{6}$, dan aquabides. Semua bahan kimia yang digunakan berderajat pro analisis.

\section{Prosedur Penelitian}

Penentuan waktu deposisi optimum

Variasi waktu deposisi yang digunakan adalah $30 ; 60 ; 90 ; 120$; dan 150 detik dengan kecepatan pengadukan $2000 \mathrm{rpm}$ dan waktu diam (quiet time) 30 detik. Pengukuran dilakukan dengan metode SWSV dengan kisaran potensial $-1,4 \mathrm{~V}$ sampai +0,4 V terhadap $\mathrm{Ag} / \mathrm{AgCl}$, potensial deposisi $-1,2 \mathrm{~V}$ dan scan rate 15 $\mathrm{mV} / \mathrm{s}$.

\section{Penentuan laju pindai (scan) optimum}

Parameter pengukuran yang diterapkan yaitu, potensial deposisi -1,2 V, kecepatan pengadukan $2000 \mathrm{rpm}$ selama waktu deposisi optimum, dan waktu diam (quiet time) 30 detik. Kecepatan scan diatur bervariasi yaitu $510,15,20,25$ dan 30 $\mathrm{mV} /$ detik dan scan potensial $-1,4$ sampai $+0,4 \mathrm{~V}$.

\section{Penentuan kalibrasi linear}

Penentuan kalibrasi linear dilakukan dengan cara membuat larutan standar logam dengan konsentrasi yang bervariasi mulai dari 1, 2, 3, 5, 10, 20, 50, 100, 200,
500, 1000, 1500 dan 2000 ppb. Arus yang terukur $(y)$ dibuat plot dengan konsentrasi larutan $(x)$. Rentang konsentrasi linier adalah rentang konsentrasi logam yang menghasilkan persamaan garis lurus $(y=$ $a+b x)$ dengan nilai $r^{2}$ yang mendekati 1,00 .

\section{Penentuan limit deteksi}

Limit deteksi pengukuran adalah konsentrasi terkecil yang masih memberikan sinyal analit yang dapat terukur oleh instrumen, yang dapat ditentukan dengan persamaan 1, 2 dan 3. Dengan $S_{y / x}$ adalah kesalahan regresi, a adalah intersep dan $b$ adalah slope (Hibbert and Gooding, 2006).

$$
\begin{gathered}
L_{o} D=\frac{3 S_{y / x}}{b} \\
S_{y / x}=\sqrt{\frac{\sum\left(y_{i}-\hat{y}_{i}\right)^{2}}{n-2}} \\
\hat{y}_{i}=a+b x
\end{gathered}
$$

\section{Penentuan keberulangan pengukuran}

Pengukuran dilakukan sebanyak 10 kali pada konsentrasi ion logam masingmasing $500 \mathrm{ppb}$ dengan menggunakan kondisi yang diperoleh pada tahap optimasi.

\section{Persen perolehan kembali (\% recovery)}

Persenperolehan kembali ditentukan dengan membandingkan konsentrasi yang diukur oleh alat dan konsentrasi larutan standar yang telah diketahui. Jika diperolah nilai yang mendekati $100 \%$ menunjukkan akurasi hasil pengukuran yang baik.

\section{Persiapan dan pengukuran konsentrasi $\mathrm{Cu}$ (II) dalam sampel}

Sampel tanaman kangkung diambil dengan cara: seluruh bagian tanaman dari akar hingga pucuk diambil dan dicuci, dikeringkan selama 24 jam dalam suhu 
kamar. Sampel dipotong-potong lalu ditimbang kemudian dikeringkan dalam oven pengering $\left(80^{\circ} \mathrm{C}\right)$, kemudian sampel ditimbang kembali sampai mendapatkan berat konstan untuk menentukan kadar air pada sampel kangkung. Sampel yang telah kering kemudian dihaluskan dengan ditumbuk. Sampel kering ditimbang sebanyak 1 gram dimasukkan dalam gelas beaker, ditambahkan $20 \mathrm{~mL}$ aqua regia, kemudian dipanaskan di atas hot plate dalam lemari asam sampai larut sempurna. Filtrat yang diperoleh diencerkan dengan aquabides sehingga diperoleh larutan sebanyak $25 \mathrm{~mL}$.

Kadar logam $\mathrm{Cu}$ ditentukan dengan metode adisi standar. Sebanyak lima buah labu ukur digunakan sebagai wadah sejumlah sampel dan larutan standar dengan komposisi volume larutan yang digunakan yaitu $2 \mathrm{~mL}$ sampel dan variasi penambahan standar yaitu $0 ; 1 ; 2 ; 3$; dan 5 $\mathrm{mL}$. Selanjutnya masing-masing larutan diencerkan dengan $0,1 \mathrm{M}$ larutan $\mathrm{H}_{2} \mathrm{SO}_{4}$ hingga tanda batas.Sampel yang mengandung larutan standar dimasukkan ke dalam sel voltameter. Pengukuran kadar logam dilakukan pada kondisi waktu deposisi dan kecepatan scan optimum.

\section{Hasil dan Pembahasan}

\section{Penentuan Waktu Deposisi Optimum}

Waktu deposisi adalah waktu yang diperlukan untuk mereduksi ion logam menjadi logamnya pada permukaan elektroda. Data voltamogram larutan standar $\mathrm{Cu}$ (II) 500 ppb ditunjukkan pada Gambar 1. Pada Gambar 1 dapat dilihat arus puncak larutan standar $\mathrm{Cu}$ (II) mengalami peningkatan dari 30 detik sampai 60 detik kemudian mengalami penurunan. Berdasarkan hal tersebut dapat diketahui bahwa sebelum waktu deposisi optimum logam belum jenuh terdeposisi di permukaan elektroda kerja dan setelah waktu deposisi optimum permukaan elektroda sudah jenuh dengan ion logam. Pada waktu deposisi optimum terjadi kesetimbangan reaksi redoks pada permukaan elektroda glassy carbon.

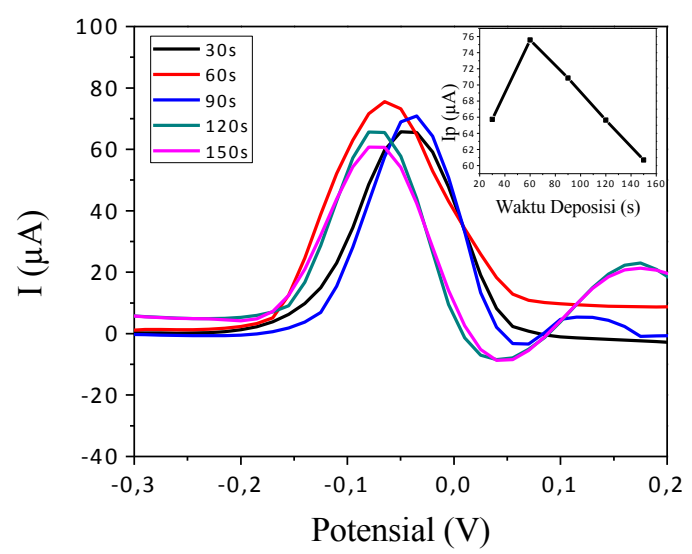

Gambar 1. Voltamogram larutan standar $\mathrm{Cu}$ (II) $500 \mathrm{ppb}$ dengan variasi waktu deposisi.

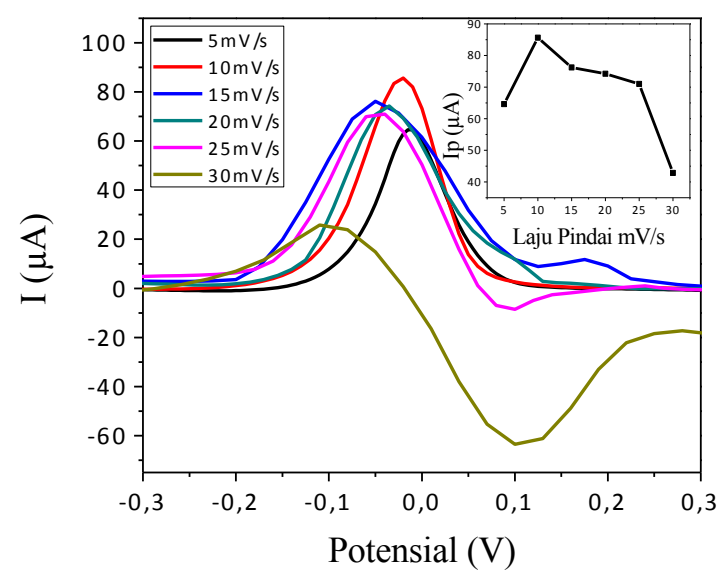

Gambar 2. Voltamogram larutan standar $\mathrm{Cu}$ (II) $500 \mathrm{ppb}$ dengan variasi kecepatan pindai.

Penentuan kecepatan pindai (scan) optimum

Kecepatan pindai optimum ditentukan untuk mengetahui kecepatan pindai yang menghasilkan arus puncak paling tinggi.Kecepatan pindai diperoleh dengan mengatur increment yaitu kenaikan pulsa, pada amplitudo dan frekuensi yang konstan.Pada larutan standar $\mathrm{Cu}$ (II) 500 ppb diperoleh data voltamogram sesuai dengan Gambar 2. Pada Gambar 2 diperoleh kecepatan pindai optimum larutan standar $\mathrm{Cu}$ (II) 500 ppb 10 $\mathrm{mV} /$ detik. Pada kecepatan pindai optimum terjadi kesetimbangan laju 
reaksi untuk reaksi reduksi dan reaksi oksidasi pada permukaan elektroda glassy carbon.

\section{Penentuan rentang konsentrasi linear}

Rentang konsentrasi linier ditentukan untuk mengetahui rentang konsentrasi yang memberikan hubungan linier antara sinyal yang dihasilkan oleh instrumen dengan konsentrasi analit (Harvey, 2000). Rentang konsentrasi linier larutan standar $\mathrm{Cu}$ (II) ditentukan dengan membuat larutan standar dengan rentang konsentrasi 1 ppb - 2000 ppb dan pengukuran arus puncak dilakukan sesuai dengan kondisi optimum yang telah didapatkan sebelumnya. Kurva kalibrasi larutan standar $\mathrm{Cu}$ (II) ditunjukkan pada Gambar 3. Pada konsentrasi 50 ppb - 500 ppb untuk logam $\mathrm{Cu}$ (II) kenaikan arus puncak berbanding lurus dengan kenaikan konsentrasi, sehingga memperoleh hubungan yang linear antara konsentrasi dengan arus puncak. Hubungan linier antara konsentrasi dengan arus puncak yang dibuktikan dengan nilai regresi $\mathrm{Cu}$ (II) yang mendekati satu yaitu 0,9966. Hasil pengukuran pada konsentrasi di bawah $50 \mathrm{ppb}$ dan di atas 500 ppb tidak menghasilkan kenaikan arus puncak yang signifikan dengan kenaikan konsentrasi.

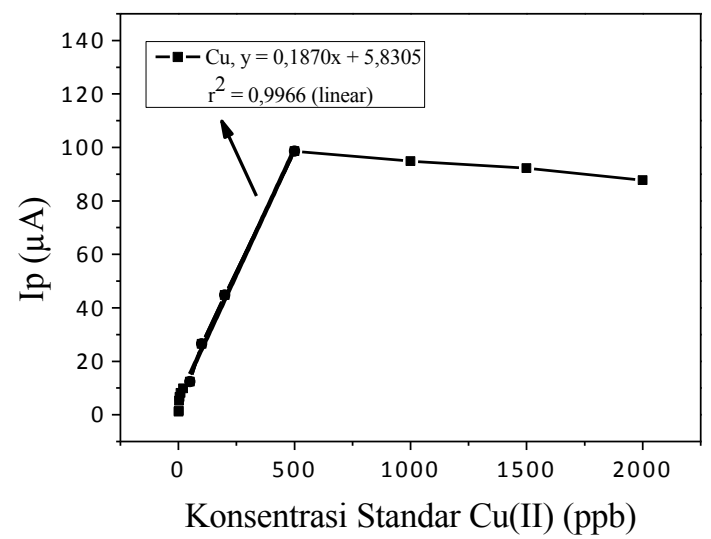

Gambar 3. Kurva kalibrasi larutan standar $\mathrm{Cu}$ (II)

\section{Penentuan limit deteksi}

Limit deteksi ditentukan untuk mengetahui konsentrasi terkecil dari analit yang memberikan sinyal yang bisa dibedakan dari sinyal blanko (Harvey, 2000). Berdasarkan hasil perhitungan diperoleh limit deteksi dari larutan standar $\mathrm{Cu}$ (II) sebesar $35 \mathrm{ppb}$. Limit deteksi menunjukkan kadar minimum ion logam yang dapat terdeteksi oleh instrumen.

\section{Keberulangan pengukuran}

Keberulangan pengukuran adalah salah satu uji presisi yang menunjukkan derajat kesesuaian hasil uji yang diukur melalui penyebaran hasil dari rata-rata jika prosedur ditetapkan secara berulang. Penentuan keberulangan pengukuran dilakukan dengan menggunakan larutan standar logam $\mathrm{Cu}$ (II) 500 ppb pada kondisi optimum sebanyak 10 kali pengulangan. Grafik data arus puncak dapat dilhat melalui Gambar 4. Nilai standard deviation (SD), relative standard deviation (RSD), dan coefficient variation $(\mathrm{CV})$, dari logam $\mathrm{Cu}$ (II) berturut-turut yaitu 2,8044, 0,0302, dan $3,02 \%$ sedangkan hasil perhitungan rasio Horwitz diperoleh 0,17. Berdasarkan data yang diperoleh menunjukkan bahwa nilai rasio Horwitz kurang dari 2. Keberulangan pengukuran yang baik dapat diterima jika nilai rasio Horwitz kurang dari 2 (Horwitz and Albert, 2006).

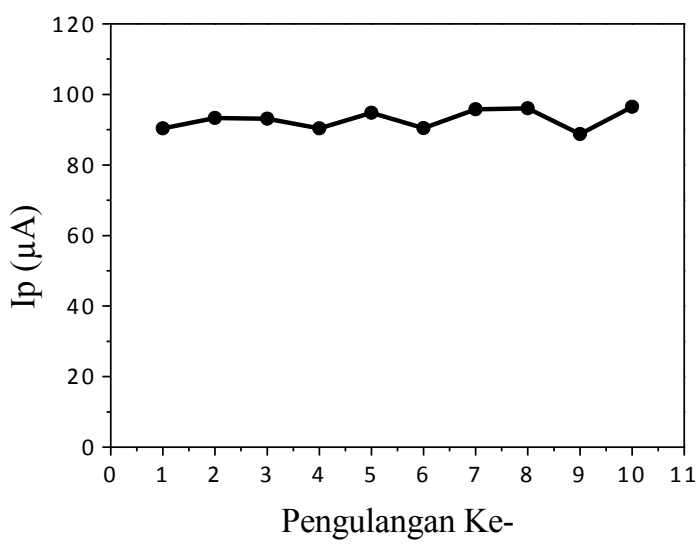

Gambar 4. Kurva keberulangan pengukuran larutan standar $\mathrm{Cu}$ (II) 500 ppb

\section{Penentuan persen perolehan kembali}

Persen perolehan kembali ditentukan dengan tujuan untuk mengukur ketepatan 
(akurasi) pengukuran instrumen terhadap hasil sebenarnya. Data arus puncak kemudian disubstitusi ke dalam persamaan garis linier sehingga diperoleh kadar logam berdasarkan pengukuran instrumen. Nilai persen perolehan kembali dari larutan standar logam $\mathrm{Cu}(\mathrm{II})$ adalah $99,35 \% \pm 0,45$.

Penentuan kadar logam cu dalam sampel tanaman kangkung dengan metode adisi standar

Sampling tanaman kangkung dilakukan di muara sungai Badung. Sampel yang telah dibersihkan dan dikeringkan di potong-potong kemudian ditimbang sebanyak 32,31 gram lalu dipanaskan dalam oven dengan suhu 80 ${ }^{\circ} \mathrm{C}$ hingga didapatkan berat konstan sebanyak 6,67 gram. Berdasarkan berat sampel yang telah didapatkan dapat diketahui kadar air dari sampel tanaman kangkung yaitu 79,36\%. Sampel tanaman kangkung didestruksi untuk memutuskan ikatan logam dengan senyawa di dalam sampel. Kadar logam Cu (II) ditentukan dengan metode adisi standar. Data arus puncak yang diperoleh kemudian dibuat kurva kalibrasi dan dihitung untuk mendapatkan persamaan garis. Kurva adisi standar dan persamaan garis pengukuran sampel ditunjukkan pada Gambar 5.

Berdasarkan persamaan garis yang diperoleh, kadar logam $\mathrm{Cu}(\mathrm{II})$ pada sampel tanaman kangkung adalah 4,0ppm.Dengan demikian, sampel tanaman kangkung memiliki kandungan logam $\mathrm{Cu}$ (II) yang tidak melebihi standar berdasarkanKeputusan Direktur Jenderal Pengawasan Obat dan Makanan No:03725/B/SK/VII/89 tentang Batas Maksimum Cemaran Logam dalam Makanan untuk logam $\mathrm{Cu}$ (II) yaitu 5,0 ppm. Sumber pencemaran logam pada tanaman kangkung disebabkan oleh buangan limbah rumah tangga dan industri rumah tangga yang berada di sekitar daerah tersebut.

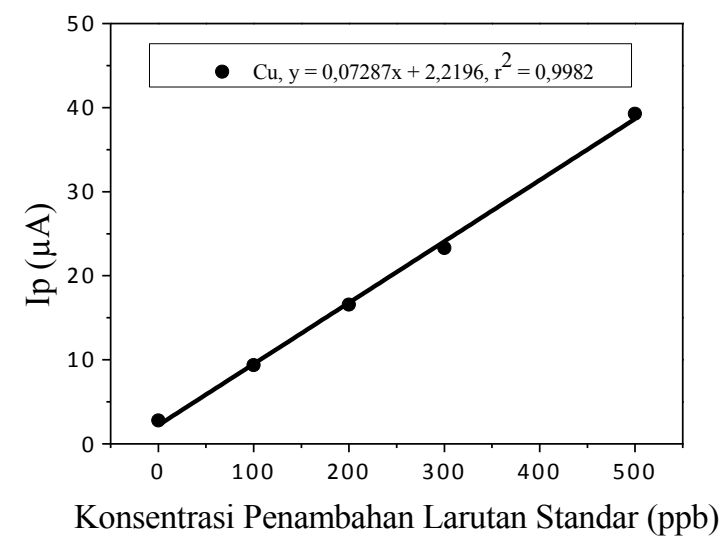

Gambar 5. Grafik uji keteguhan patah (MOR) papan partikel dengan variasi berat serbuk cangkang buah karet.

\section{Kesimpulan}

Waktu deposisi danlajupindaioptimum yang diperoleh dalampengukuran larutan standar logam $\mathrm{Cu}$ (II) sebesar 60 detik dan $10 \mathrm{mV} /$ detik menggunakan elektroda kerja glassy carbon. Pengukuran validitas larutan standar logam $\mathrm{Cu}$ (II) dengan teknik voltametri pelucutan anodik gelombang persegi menunjukkan hasil yang baik. Rentang konsentrasi linier larutan standar logam $\mathrm{Cu}$ (II) yaitu 50 500 ppb dengan koefisien korelasi 0,9983. Limit deteksi larutan standar logam $\mathrm{Cu}$ (II) $35 \mathrm{ppb}$, keberulangan pengukuran memiliki rasio Horwitz kurang dari 2, dan persen perolehan kembali sebesar 99,35\% $\pm 0,45$. Sampel tanaman kangkung memiliki kandungan logam $\mathrm{Cu}$ (II) sebesar 4,0 ppm. Berdasarkan data-data hasil analisis dapat disimpulkan bahwa kandungan logam $\mathrm{Cu}$ (II) pada sampel kangkung air tidak melebihi kadar maksimum dari yang diperkenankan.

\section{Ucapan Terimakasih}

Penulis mengucapkan terimakasih kepada setiap pihak yang telah membantu dalam menyelesaikan penelitian ini. 


\section{Daftar Pustaka}

Darmono (1995). Logam Berat dalam Sistem Biologi, UI Press, Jakarta

Departemen Kesehatan Republik Indonesia (1989). Keputusan Direktur Jenderal Pengawasan Obat dan Makanan No.03725/B/SK/VII/89 tentang Batas Maksimal Cemaran Logam Dalam Makanan, Depkes RI, Jakarta.

Harmita (2004). Petunjuk pelaksanaan validasi metode dan cara perhitungannya, Majalah Ilmu Kefarmasian, 1 (3): 177-135

Harvey, D. (2000). Modern Analytical Chemistry, $1^{\text {st }}$ ed., McGraw Hill, New York

Hibbert, D.B. and Gooding, J.J. (2006) Data Analysis for Chemistry: An Introductory Guide for Student and Laboratory Scientist, Oxford University Press, Oxford
Horwitz, W. and Albert, R. J. (2006). The Horwitz ratio (Hor rat): a useful index of method performance with respect to precision, Assoc. of Anal. Chem., 89, 1095-1109

Rachman, F.A.A. (2009). Kandungan nitrat dan timbal pada tanah dan kangkung yang diberi perlakuan air limbah, Skripsi, Institut Pertanian Bogor, Bogor

Wang, J. (2001). Analytical Electrochemistry, $2^{\text {nd }}$ ed., Wiley Publisher, New York

Widayah, S. (2010). Deteksi ion logam berat secara simultan pada elektroda boron doped diamond dengan metode anodic stripping voltametri, Tesis, Fakultas Matematika dan Ilmu Pengetahuan Alam, Program Studi Kimia S2, Universitas Indonesia, Depok 